\title{
Comparing needle and shoot phenology with xylem development on three conifer species in Italy
}

\author{
Sergio Rossi ${ }^{1}{ }^{*}$, Cyrille B.K. RATHGEBeR ${ }^{2,3}$, Annie DesLaUriers ${ }^{1,4}$ \\ ${ }^{1}$ Université du Québec à Chicoutimi, Département des Sciences Fondamentales, Chicoutimi, Canada \\ ${ }^{2}$ INRA, UMR1092, Laboratoire d Étude des Ressources Forêt Bois (LERFoB), Centre INRA de Nancy, F-54280 Champenoux, France \\ ${ }^{3}$ AgroParisTech, UMR1092, Laboratoire d Étude des Ressources Forêt Bois (LERFoB), ENGREF, 14 rue Girardet, F-54000 Nancy, France \\ ${ }^{4}$ Università degli Studi di Padova, Dipartimento TeSAF, Legnaro (PD), Italy
}

Keywords:

cambium /

cell differentiation /

latewood /

microcore /

timberline

(Received 27 August 2008; accepted 25 November 2008)

\author{
Mots-clés : \\ cambium / \\ différentiation cellulaire / \\ bois final / \\ microcarotte / \\ limite altitudinale de la forêt
}

\begin{abstract}
- Since the 1960s biologists have been trying to assess factors affecting cambial activity and latewood formation. A comparison of the phenology of the apical and lateral meristems could add new clues in order to understand mechanisms of the growth dynamic in conifers.

- This study compared needle and shoot growth with xylogenesis in Larix decidua, Pinus cembra and Picea abies during 2001 to verify if cambial resumption occurred after shoot and needle growth had begun, and if latewood initiation occurred when shoot lengthening was complete.

- In pine and spruce, needle and shoot lengthening was synchronous between mid-June and August while larches showed an early development of the needles at the end of May with a later shoot lengthening. Cell production lasted from mid-May to the beginning of August, with the first differentiating cells observed at the end of May, which indicated a earlier reactivation of the cambium with respect to needle and shoot growth.The first latewood cells began wall thickening between July and August, during the termination of needle and shoot lengthening.

- The hypothesis that cambial resumption occurs after shoot and needle elongation was rejected. The separation in time between apical growth and secondary wall thickening of latewood suggested the presence of an internal competition in resource allocation.
\end{abstract}

Résumé - Comparaison entre la phénologie des aguilles et des pousses et la formation du xylème sur trois espèces de conifère en Italie.

- Depuis les années soixante, les biologistes étudient les facteurs contrôlant l'activité cambiale et la formation du bois final. Une comparaison entre la phénologie des méristèmes apicaux et latéraux pourrait ajouter de nouveaux indices afin de mieux comprendre les mécanismes et la dynamique de croissance des conifères.

- Cette étude compare la croissance des aiguilles et des nouvelle tiges avec la xylogénèse de trois espèces de conifères, Larix decidua, Pinus cembra et Pices abies dans le but de vérifier si la réactivation cambiale survient après la croissance des aiguilles et des nouvelles pousses et si la formation du bois final survient lorsque la croissance des méristèmes apicaux et latéraux est terminée.

- Chez le pin et l'épicéa, la croissance des aiguilles et des nouvelles pousses était synchrone, se produisant de la mi-juin jusqu'au début août. Chez le mélèze par contre, le développement des aiguilles a été plus précoce, débutant fin mai avec une croissance différée des tiges latérales. La production cellulaire du cambium a durée de mi-mai jusqu'à début août, avec apparition des premières cellules en différentiation fin mai, indiquant une réactivation plus précoce du cambium que de la croissance des aiguilles et des nouvelles pousses. L'épaississement des parois secondaires chez les premières cellules de bois final a débuté entre juillet et août, à la fin de l'élongation des aiguilles et des nouvelles pousses.

- L'hypothèse que la réactivation cambiale survient après la croissance des aiguilles et des nouvelles pousses a été rejetée. La séparation dans le temps entre les croissances apicale et latérale et l'épaississement des parois secondaires du bois final a suggéré la présence d'une compétition interne dans l'allocation des ressources.

\footnotetext{
* Corresponding author: sergio.rossi@uqac.ca
} 


\section{INTRODUCTION}

Although seasonal dynamics of wood formation has been analyzed thoroughly in the last decade, the factors influencing cambial activity and their mechanisms of action still remain to be clearly identified and precisely quantified. On the one hand, the influence of environmental factors, well documented in dendroecology through climate-growth relationships (Schweingruber, 1996), was demonstrated to be complicated by the asynchronous and long lasting production and maturation of xylem cells (Deslauriers et al., 2007; 2008; Fonti et al., 2007; Seo et al., 2008). On the other, the dynamics of wood formation is strongly determined by internal factors, such as cambial age, carbohydrate availability and hormone distribution (Rossi et al., 2008; Uggla et al., 1998; 2001). In particular, since the 1960 s biologists have been trying to explain (or interpret) the influence of auxin on cambial activity and latewood formation (Aloni 2001; Avery et al., 1937; Denne and Wilson, 1977; Larson, 1969). Since this hormone is produced in the younger growing needles of plants and exported basipetally into the subjacent stem (Savidge, 1988; Sundberg and Uggla, 1998), a comparative assessment of the phenology of primary (apical meristems) and secondary (cambium) meristems could add new clues in order to understand the growth dynamics of a tree as a whole.

Auxin participates in the reactivation of the vascular cambium, inducing the production of xylem and phloem (Larson, 1969) and regulating rate and duration of the developmental processes during xylogenesis (Tuominen et al., 1997; Uggla et al., 1998). Larson's hypothesis affirms that, with the auxin basipetal movement, periclinal divisions in the cambium should also begin at the base of the buds and spread downwards towards the stem (Denne, 1979; Lachaud et al., 1999; Larson, 1969). Meristems in buds and cambium should be thereby closely interrelated and, as a consequence of the basipetal hormone flow, cambial activity at the stem base should be delayed with respect to the activity of the terminal meristems.

In diffuse porous species, cambial reactivation takes place immediately after budbreak (Čufar et al., 2008; Schmitt et al., 2000). On the contrary, cell division to produce xylem in the lower stem of ring porous species begin before bud opening (Ladefoged, 1952). For conifer species, the available literature on bud phenology and cambial growth is scarce. In addition, when compared, data appear contradictory. On the seven studied conifers, budbreak occurred either before or after the onset of xylem cell production (Ladefoged, 1952; O'Reilly and Owens, 1989; Rensing and Owens, 1994). Consequently, no definitive pattern emerges and the link between these two meristems still remains unclear.

Kramer (1964) reported that the transition from earlywood to latewood begins after the first severe water deficit occurs. However, this proposition has had to be abandoned because latewood cells are observed even in trees living with unlimited water conditions. It is argued that latewood formation is connected with shoot phenology, as Larson (1964) found that the transition from earlywood to latewood in Pinus resinosa was associated with cessation of needle growth. More recently, a similar result was also observed in seedlings of Abies balsamea (Rossi et al., in press). Decreases in auxin supply or alteration of auxin concentration gradients in the developing tissues following cessation of shoot and/or needle lengthening could be the cause of latewood formation in the xylem (Sundberg et al., 2000). However, the lack of a direct correlation between cessation of leader growth and latewood formation in Pseudotsuga menziesii suggested that these two phenomena may occur at the same time but might not be connected by a causal relationship (Renninger et al., 2006).

This study compared the intra-annual dynamics of growth in needles, shoots and stems of deciduous and evergreen conifers at the Alpine timberline in 2001. The aim was to test the following two hypotheses: (i) cambial resumption occurs after shoot and needle growth has begun, and (ii) latewood initiation occurs when shoot lengthening is completed.

\section{MATERIAL AND METHODS}

\subsection{Study area and tree selection}

The study site was in a permanent plot located at $2080 \mathrm{~m}$ a.s.l. close to the Cinque Torri mountain group (Cortina d'Ampezzo, Belluno) in the eastern Italian Alps ( $\left.46^{\circ} 27^{\prime} \mathrm{N}, 12^{\circ} 08^{\prime} \mathrm{E}\right)$, on a south facing slope with shallow calcareous soil. The forest was composed of mixed and open clumps of trees of Larix decidua Mill., Pinus cembra L. and Picea abies (L.) Karst., corresponding to the timberline ecotone (Figs. 1A and 1B). At the site, mean annual temperature is $2.4{ }^{\circ} \mathrm{C}$, with annual precipitation of $1150 \mathrm{~mm}$ and June-August precipitation of about $500 \mathrm{~mm}$.

Fifteen dominant trees of L. decidua, P. cembra and P. abies (five trees per species) with upright stems and homogeneous diameters were chosen in the plot (Tab. I). Trees with polycormic stems, partially dead crowns, reaction wood or evident damage were avoided. Trees were selected after having assessed growth rate homogeneity by counting the number of tracheids in the tree rings of the three preceding growing seasons, and the absence of reaction wood (Deslauriers et al., 2003). During 2001, all trees were measured each week from May to September in order to assess intra-annual dynamics of apical and cambial meristems.

\subsection{Needle and shoot measurements}

In April, north- and south-exposed branches were selected on each tree and two branches per exposure located at a height of $1.5-2 \mathrm{~m}$ from the soil were marked with tape. Because of the low site density, the selected trees could be considered as isolated and none of the south-exposed branches were shaded by crowns of other plants (Figs. 1A and 1B). On the branches, the developing apical shoots were measured each week with a precision manual calibre to the nearest $1 \mathrm{~mm}$. Five developing needles on each shoot were also randomly selected and measured weekly. These measurements collected in the lower branches could properly represent the dynamics of shoot and needle growth of the whole crown (Tang et al., 1999). 

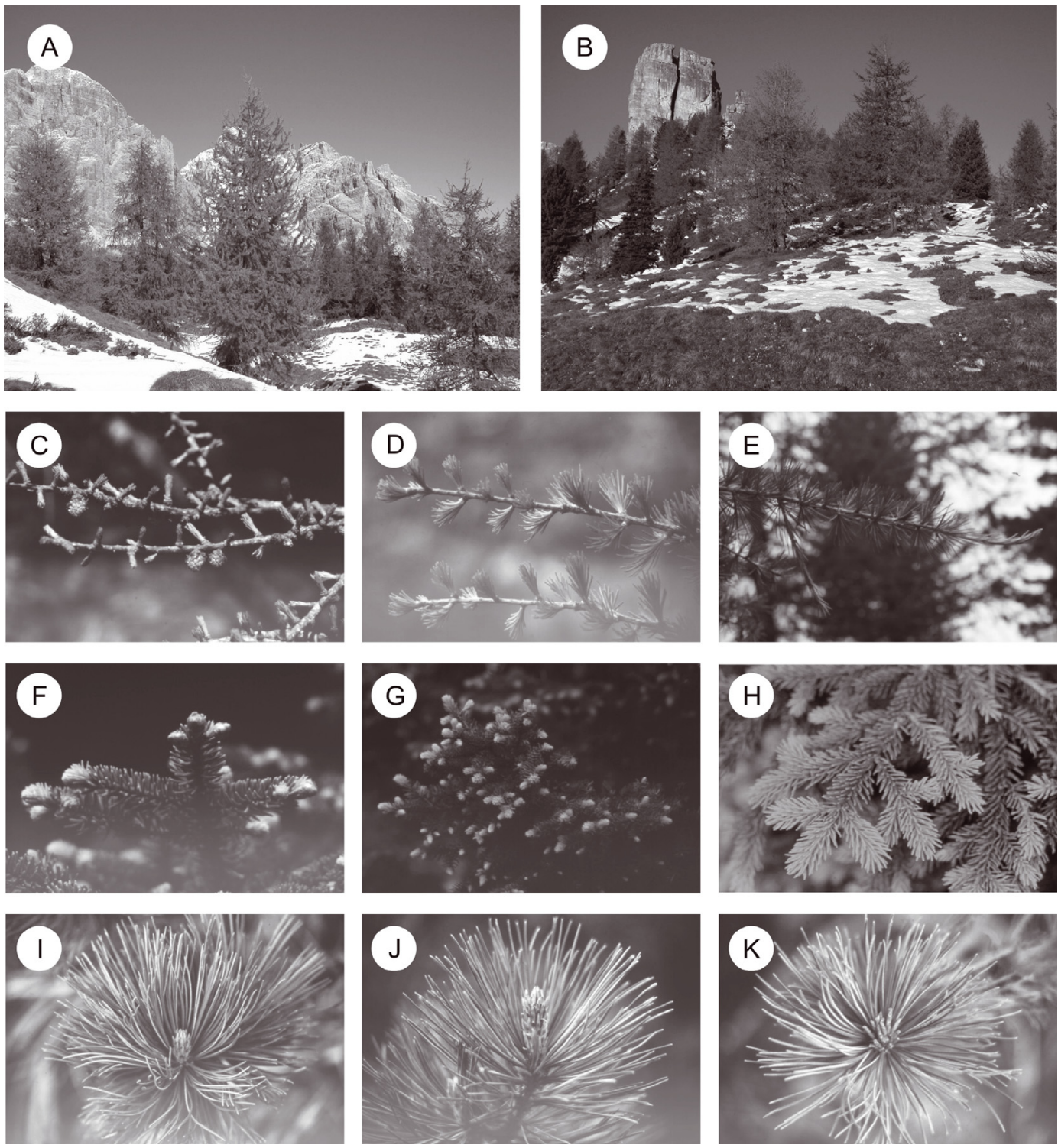

Figure 1. Appearance of the mixed open forest in the Cinque Torri area corresponding to the timberline ecotone (A-B) and bud phenology of the three studied conifers (C-K). Needle (C-D) and shoot (E) development in Larix decidua. Budbreak (F), needle and shoot (G) growth and final size of branches $(\mathrm{H})$ in Picea abies. Budbreak $(\mathrm{I})$, shoot $(\mathrm{J})$ and needle $(\mathrm{K})$ growth in Pinus cembra.

Table I. Age and size of the sampled trees reported as mean and standard deviation.

\begin{tabular}{lccc}
\hline Species & Age & Diameter $(\mathrm{cm})$ & Height $(\mathrm{m})$ \\
\hline L. decidua & $60.6 \pm 18.7$ & $26.8 \pm 4.8$ & $11.6 \pm 1.0$ \\
P. cembra & $60.4 \pm 7.9$ & $29.2 \pm 8.6$ & $10.1 \pm 0.7$ \\
P. abies & $45.0 \pm 8.7$ & $22.4 \pm 6.2$ & $10.4 \pm 0.6$ \\
\hline
\end{tabular}

\subsection{Xylem collection and observation}

Wood microcores (2.4 $\mathrm{mm}$ in diameter) were weekly collected around the stems at DBH $(1.3 \mathrm{~m})$ using an increment puncher. The reduced invasiveness of microcoring has demonstrated to allow repetitive samplings during the year on the same trees with reduced dam- age to the tissues and no significant influence on stem growth (Forster et al., 2000). In L. decidua and P. cembra, the thick dead outer bark was removed before sampling. The samples usually contained the preceding 4-5 tree rings and the developing annual layer with the cambial zone and adjacent phloematic tissue. Immediately after sampling, the microcores were placed in Eppendorf microtubes with an ethanol solution (50\% in water) and stored at $5{ }^{\circ} \mathrm{C}$ in order to avoid tissue deterioration. Each sample was oriented by marking the transversal side with a pencil under a stereo-microscope at magnification of 10-20×. The microcores were dehydrated with successive immersions in ethanol and D-limonene, embedded in paraffin according to Rossi et al. (2006a) and transverse sections of 6-10 $\mu \mathrm{m}$ thickness were cut with a rotary microtome.

Sections were stained with cresyl fast violet $(0.05 \%$ in water $)$ and examined within 10-25 min with visible and polarized light 
at magnifications of $400-500 \times$ to distinguish the developing xylem cells. For each section, the radial number of (1) radial enlarging, (2) cell-wall thickening, and (3) mature cells were counted along three radial files according to Rossi et al. (2006b). In cross section, cambial cells were characterized by thin cell walls and small radial diameters. During enlargement, the tracheids still showed thin cell walls but radial diameters at least twice those of the cambial cells. Observations under polarized light discriminated between enlarging and cell wall thickening tracheids. Because of the arrangement of the cellulose microfibrils, the developing secondary walls glistened when observed under polarized light, whereas no glistening was observed in enlargement zones where the cells were still just composed of primary wall (Abe et al., 1997). The progress of cell wall lignification was detected with cresyl fast violet reacting with the lignin (Antonova and Shebeko, 1981). Lignification appeared as a colour change from violet to blue. This colour change over the whole cell wall revealed the end of the lignification process and the reaching of tracheid maturity (Gričar et al., 2005).

The sections collected during the last sampling days were stained with safranin $\left(1 \%\right.$ in water) and fixed with Eukitt ${ }^{\circledR}$. A camera fixed on an optical microscope was used for recording numerical images at magnification of $250 \times$. Cell features (lumen area, radial diameter and wall thickness) were measured on three radial files per section using an image analysis system specifically designed for wood cells (WinCELL ${ }^{\mathrm{TM}}$ ). Tracheids were classified as belonging to earlywood or latewood according to Mork's formula, which classified all cells with lumen smaller than twice a double wall as latewood (Denne, 1988).

\subsection{Statistical analyses}

Initiation of needle and shoot elongation was assessed when the average of measurements was statistically different from zero (Student t-test). For each tree, when at least one row of enlarging cells was observed, cambial activity and xylem differentiation were considered to have started in the xylem. When the last cells in wall-thickening phase matured at the end of the growing period, xylem formation was completed (Rossi et al., 2006b). For statistical comparisons, the dates of beginning of cell differentiation and needle and shoot lengthening were converted into days of the year. Because the assumption of normality in data distribution within each group was frequently violated, all comparisons were performed using nonparametric Kruskal-Wallis tests.

\section{RESULTS}

Different patterns of needle and shoot growth were observed in the three species (Figs. 1C-1K). Larch showed early development of the needles at the end of May, while shoot lengthening occurred one month later, when needles had reached their maximum length of $18-20 \mathrm{~mm}$ (Figs. 2A and 2D). Different dates of beginning of needle and shoot growth were also detected by statistical comparisons (Kruskal-Wallis test, $\chi^{2}=6.67, p<0.01$ ). Shoot lengthening in larch was complete at the end of July. In spruce, needle and shoot lengthening was synchronous and occurred between mid-June and mid-July (Figs. 2B and 2E), although an earlier beginning of needle growth was observed (Kruskal-Wallis test, $\chi^{2}=6.35$, $p<0.05)$. A duration of 35 days of shoot and needle lengthening was estimated for both larch and spruce. Pine took longer, requiring 49 days to complete needle and shoot growth (Figs. 2C and 2F). In pine, bud burst showed 7-10 mm length needles still enclosed into the basal scales grouping the needle bundles and, although measurements were statistically different from zero during the first sampling day ( $t$-test, $t=34.04$, $p<0.05$ and $t=50.83, p<0.05$ for north- and south-exposed branches, respectively), were considered still quiescent. Vigorous lengthening of needles began four weeks later, in the same period as shoot growth (Kruskal-Wallis test, $\chi^{2}=0.12, p>$ $0.05)$. With respect to north-exposed branches, south-exposed shoots, and to a lesser degree needles, had larger dimensions in all three species. Moreover, in larch and spruce, 1-2 weeks of delay were observed at the beginning of shoot lengthening in north-exposure. However, shoot and needle growth stopped at approximately the same time in the two exposures.

On the first sampling day, at the end of May, 1-7 enlarging cells were observed in the developing tree rings (Figs. 2G-2I). This indicated an earlier reactivation of the cambium with respect to shoot growth, which was confirmed for all three species by the statistical comparisons (Kruskal-Wallis test, $p<0.05$ for larch and $p<0.01$ for both spruce and pine). Differences between the onset of xylem differentiation and needle lengthening were also statistically significant with $p<0.05$ for larch (Kruskal-Wallis test) and lower $p$-values observed for spruce and pine (Kruskal-Wallis test, $p<0.01$ ). Cells were observed in enlargement until the beginning of August in pine and the end of August in larch and spruce. Cell wall thickening was observed to begin in early June. Xylem differentiation as a whole lasted for at least 126 days until the end of September. At which time, in spruce an average of 10 cells were still in the wall thickening phase. The total number of cells in the tree ring was observed to increase during spring and early summer until reaching a plateau, corresponding to the end of cell division in the cambium. Cell production lasted for 80 days from mid-May to the beginning of August. After that date, the total number of cells could occasionally decrease, due to the different amount of xylem produced around the stem. Larch and pine produced $38.8 \pm 3.8$ and $52.6 \pm 4.8$ tracheids during 2001. A higher rate of growth was observed in spruce, which produced $70.7 \pm 4.0$ tracheids in the tree ring.

Anatomical measurements provided curves of cell size variation, called tracheidograms, along radial files of xylem (Fig. 3). In the three species, larger tracheids with thinner cell walls were produced at the beginning of the growing season. Along the radial file, cell sizes in larch suddenly reduced from 1200 to $100 \mu \mathrm{m}^{2}$ of lumen area and from 50 to $20 \mu \mathrm{m}$ in diameter. Lower values and more gradual reductions were observed for spruce and pine, with lumen areas varying between 800 and $200 \mu \mathrm{m}^{2}$ and cell diameter ranging between 40 and $20 \mu \mathrm{m}$. In larch, single wall thickness increased along the tree ring from 2.5 to $7 \mu \mathrm{m}$. A less marked increase was observed in spruce and pine, with the last tracheids showing walls only twice those of the first produced cells.

A different amount of latewood was calculated between the three species (Fig. 3, grey area). In larch, 57\% of xylem cells were classified as latewood. Lower percentages were observed 

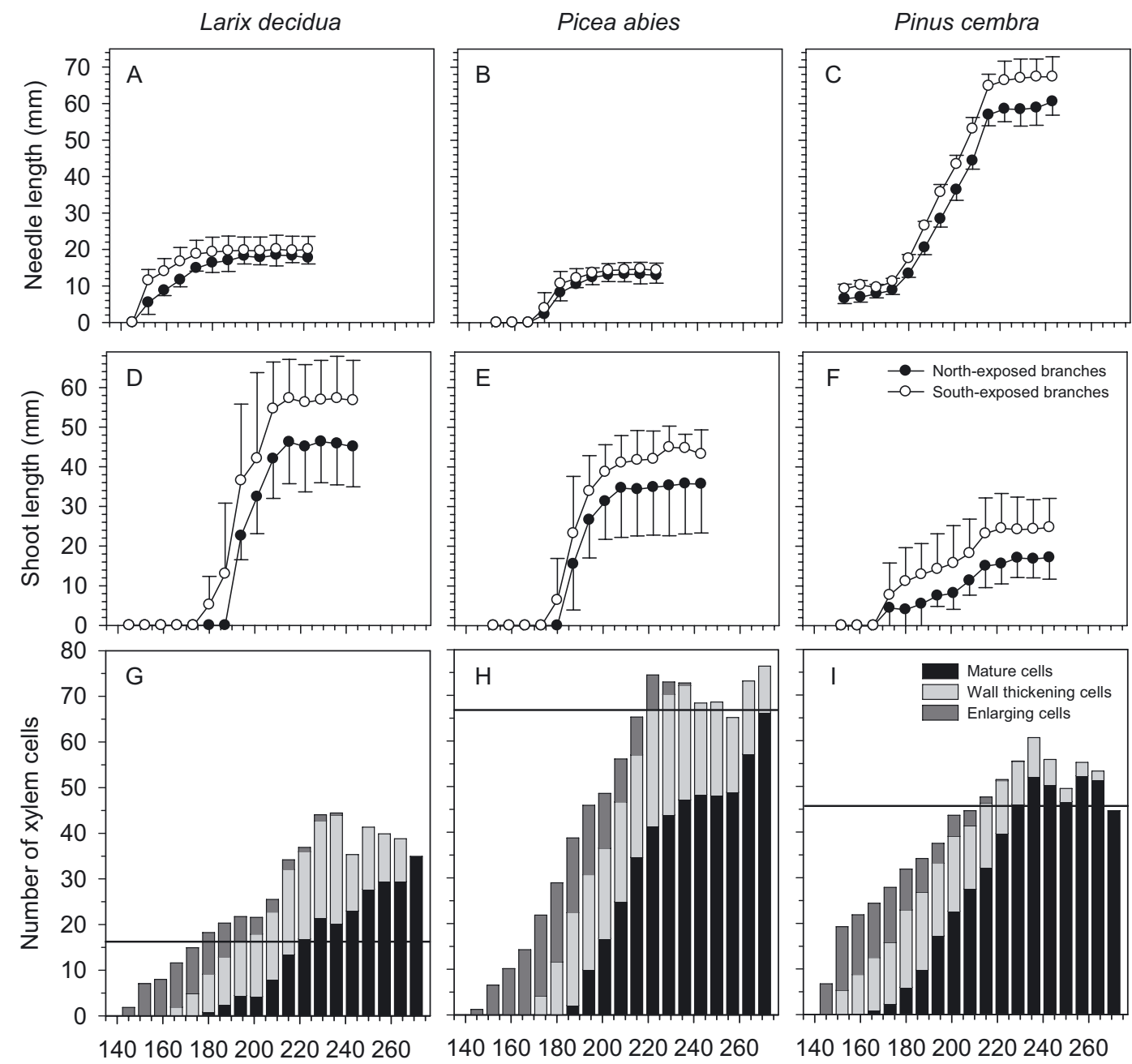

Day of the year

Figure 2. Needle (A-C) and shoot (D-F) length of north- and south-exposed branches and (G-I) accumulation of developing and mature cells in xylem of L. decidua, P. abies and P. cembra at Cinque Torri during 2001. Dots and error bars correspond to means and standard deviations. Horizontal bars separate earlywood from latewood.

in spruce and pine, with 3 and $9 \%$ of latewood in the tree ring respectively. The first latewood cells were estimated to be produced from the cambium at the end of June in larch and at the beginning of August in spruce and pine (Figs. 2G-2I). These first latewood cells began wall thickening during the second half of July in larch and at mid-August in spruce and pine. By those dates, Needle and shoot lengthening was completed in the three species. Mature latewood appeared in August in larch and pine and only at the end of September in spruce.

\section{DISCUSSION}

According to the results of this study, the hypothesis that cambial resumption occurs after shoot and needle elongation should be rejected. It means that the increase in auxin concentration produced by the developing needles could not com- pletely explain the beginning of xylogenesis of conifers in spring. Artificially warmed cambia of evergreen conifers could reactivate growth in the absence of new shoots and leaves even if the response to the heat treatment tended to increase from winter to early spring (Oribe et al., 2001). Savidge and Wareing (1982) suggested that auxin transfer to the cambial region from both mature needles and dormant buds could also occur in winter. Moreover, Little and Wareing (1981) reported unpublished works referring to vigorous cambial activities occurring in conifer trees completely debudded before the start of the growing season. There is evidence that the auxin required for cambial resumption is available in dormant conifer tissues in autumn and winter (Little and Wareing, 1981; Sundberg et al., 1991) and the beginning of stem growth in spring could be connected to a change in the cambium ability to respond to the auxin stimulation and not to an increase in auxin concentration. 

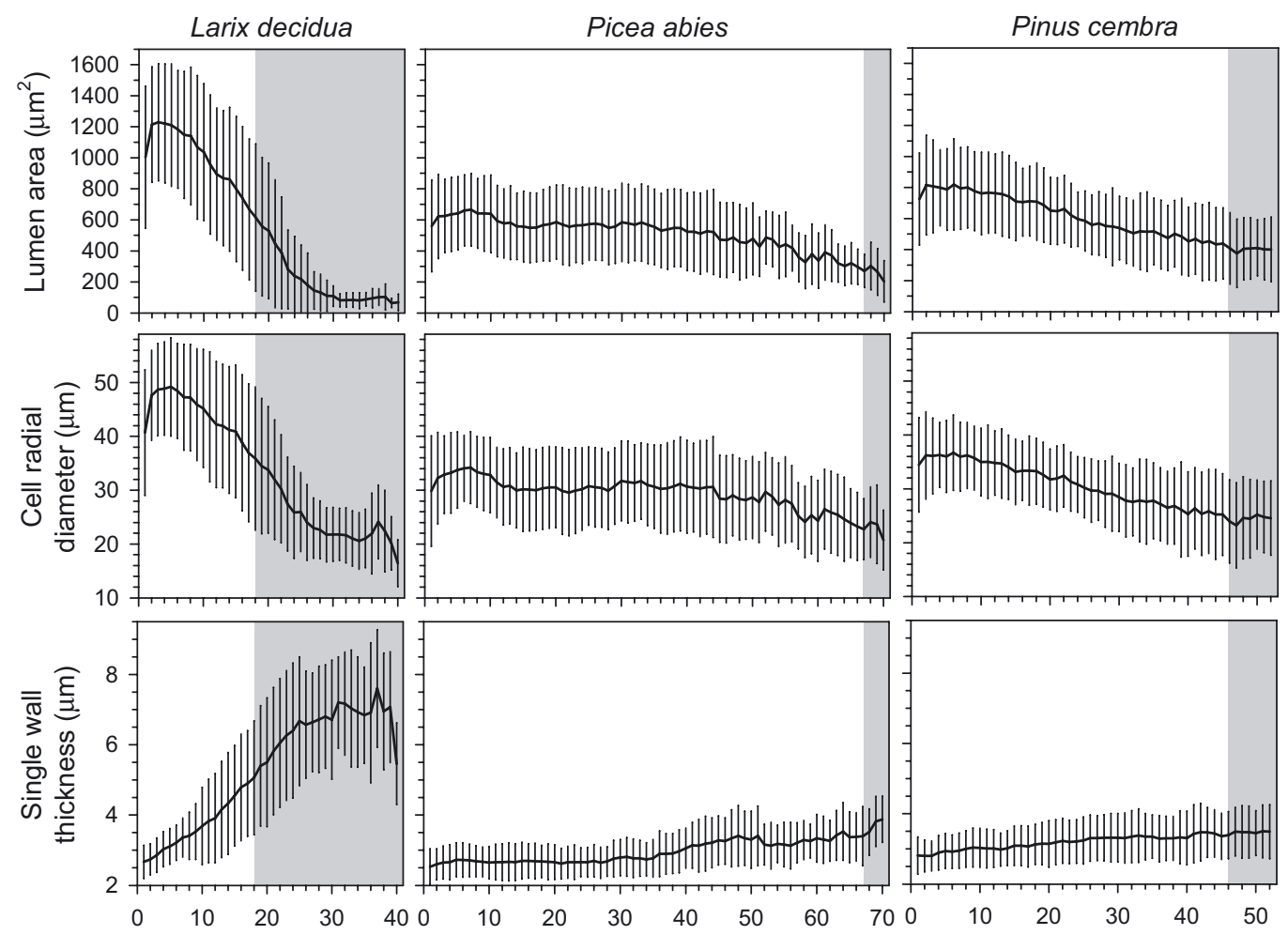

Number of cells along the tree ring

Figure 3. Cell lumen area $\left(\mu \mathrm{m}^{2}\right)$, radial diameter $(\mu \mathrm{m})$ and single wall thickness $(\mu \mathrm{m})$ of tracheids produced in 2001 by L. decidua, P. abies and P. cembra at Cinque Torri. Vertical bars represent the standard deviation. Grey windows indicate cells belonging to latewood.

Results showed a later resumption of needle and shoot growth with respect to xylem differentiation in the stem for the three timberline species, except for needle lengthening in larch. This species showed also different pattern of cell size variation along the tree ring with tracheids in larch attaining $30-35 \%$ larger diameters than in pine and spruce. Because of their deciduous leaf habit, larches evolved different morphological and physiological characteristics in order to provide a carbon gain comparable to the other conifers and survive in the evergreen-dominated forest environments (Givnish, 2002; Gower and Richards, 1990). Unlike evergreen conifers, whose long-lived needles offer a potentially longer photosynthetic season, larch needs to rebuild its crown three weeks earlier than pine and spruce to rapidly begin photosynthesis in spring. The larger earlywood tracheids associated with low osmotic component of water potential allow larches to sustain high transpiration and, consequently, high photosynthetic rates also at reduced soil water availabilities (Badalotti et al., 2000). According to Anfodillo et al. (1998), the smaller diameters of tracheids in pine and spruce correspond to the higher wateruse efficiency of evergreen conifers.

In the three species, wall thickening of latewood cells occurred after needle and shoot lengthening was completed. These results support the second hypothesis, also confirming previous works on Pseudotsuga menziesii and Abies balsamea (Emmingham, 1977; Rensing and Owens, 1994; Rossi et al., in press). Cambium is a sink of carbohydrates and cambial activ- ity requires a continuous supply of energy, extracted from the storage tissues or produced by photosynthesis (Oribe et al., 2003). The conclusion of shoot and needle lengthening occurred in July, when cambium activity slowed down (Rossi et al., 2006c). Newly produced carbon obtained from photosynthesis could be available for the deposition of cellulose microfibrils and lignin in order to provide the developing latewood cells with thick secondary walls.

According to Uggla et al. (2001), the thicker cell walls of latewood are connected to the duration rather than the rate of wall material deposition. Throughout the growing season, the time spent in wall thickening and lignification increases considerably in the studied species, from a few days for the first tracheids produced up to 40 days for one cell of latewood in L. decidua and P. abies (Rossi et al., 2006b). So, the separation in time between shoot growth and secondary wall thickening could reflect an internal competition for carbohydrates. As shoots have a higher ranking priority than cambium as a sink for carbon (Giovannelli et al., 2007; Minchin and Lacointe, 2005), only after shoots complete growth, could resources be allocated to the expending process of secondary wall formation of latewood cells (Renninger et al., 2006).

This study compared the seasonal activity of apical and cambial meristems by measuring the dynamics of needle, shoot and stem growth. In the three timberline species, latewood initiation occurred once shoot lengthening was completed but the hypothesis that cambial resumption occurred 
only after shoot and needle elongation had begun was rejected. Although it is not possible to draw definitive conclusions on plant physiology from these clear but indirect evidences, results indicate the need to deepen mechanisms of growth and relationships between meristems within a tree and to assess the role of auxin on cambial activity and wood formation by direct measurements.

\section{REFERENCES}

Abe H., Funada R., Ohtani J., and Fukazawa K., 1997. Changes in the arrangement of cellulose microfibrils associated with the cessation of cell expansion in tracheids. Trees 11: 328-332.

Aloni R., 2001. Foliar and axial aspects of vascular differentiation: hypotheses and evidence. J. Plant Growth Regul. 20: 22-34.

Anfodillo T., Rento S., Carraro V., Furlanetto L., Urbinati C., and Carrer M., 1998. Tree water relations and climatic variations at the alpine timberline: seasonal changes of sap flux and xylem water potential in Larix decidua Miller, Picea abies (L.) Karst. and Pinus cembra L. Ann. Sci. For. 55: 159-172.

Antonova G.F. and Shebeko V.V., 1981. Applying cresyl violet in studying wood formation, Khimiya Drevesiny 4: 102-105.

Avery G.S., Burkholder P.R., and Creighton H.B., 1937. Production and distribution of growth hormone in shoots of Aesculus and Malus, and its probable role in stimulating cambial activity. Am. J. Bot. 24: $51-58$.

Badalotti A., Anfodillo T., and Grace J., 2000. Evidence of osmoregulation in Larix decidua at Alpine treeline and comparative responses to water availability of two co-occurring evergreen species. Ann. For. Sci. 57: 623-633.

Čufar K., Prislan P., de Luis M., and Gričar J., 2008. Tree-ring variation, wood formation and phenology of beech (Fagus sylvatica) from a representative site in Slovenia, SE Central Europe. Trees 22: $749-758$.

Denne M.P., 1979. Wood structure and production within the trunk and branches of Picea sitchensis in relation to canopy formation. Can. J. For. Res. 9: 406-427.

Denne M.P., 1988. Definition of latewood according to Mork (1928). IAWA Bull. 10: 59-62.

Denne M.P. and Wilson J.E., 1977. Some quantitative effects of indoleacet acid on the wood production and tracheid dimensions of Picea. Planta 134: 223-228.

Deslauriers A., Anfodillo T., Rossi S., and Carraro V., 2007. Using simple causal modelling to understand how water and temperature affect daily stem radial variation in trees. Tree Physiol. 27: 1125-1136.

Deslauriers A., Morin H., and Begin Y., 2003. Cellular phenology of annual ring formation of Abies balsamea in the Quebec boreal forest (Canada). Can. J. For. Res. 33: 190-200.

Deslauriers A., Rossi S., Anfodillo T., and Saracino A., 2008. Cambium phenology, wood formation and temperature thresholds in two contrasting years at high altitude in Southern Italy. Tree Physiol. 28: $863-871$

Emmingham W.H., 1977. Comparison of selected Douglas-fir seed sources of cambial and leader growth patterns in four western Oregon environments. Can. J. For. Res. 7: 154-164.

Fonti P., Solomonoff N., and Garcia Gonzalez I., 2007. Earlywood vessels size of Castanea sativa records temperature before their formation. New Phytol. 173: 562-570.

Forster T., Schweingruber F.H., and Denneler B., 2000. Increment puncher: a tool for extracting small cores of wood and bark from living trees. IAWA J. 21: 169-180.
Giovannelli A., Deslauriers A., Fragnelli G., Scaletti L., Castro G., Rossi S., and Crivellaro A., 2007. Evaluation of drought response of two poplar clones (Populus $\times$ canadensis Mönch 'I-214' and P. deltoides Marsch. 'Dvina') through high resolution analysis of stem growth. J. Exp. Bot. 58: 2673-2683.

Givnish T.J., 2002. Adaptive significance of evergreen vs. deciduous leaves: solving the triple paradox. Silva Fenn. 36: 703-743.

Gower S.T. and Richards J.H., 1990. Larches: deciduous conifers in an evergreen world. Bioscience 40: 818-826.

Gričar J., Cufar K., Oven P., and Schmitt U., 2005. Differentiation of terminal latewood tracheids in silver fir trees during autumn. Ann. Bot. 95: 959-965.

Kramer P.J., 1964. The role of water in wood formation. In: Zimmermann M.H. (Ed.), The formation of wood in forest trees, Academic Press, New York, London, pp. 519-532.

Lachaud S., Catesson A.M., and Bonnemain J.L., 1999. Structure and functions of the vascular cambium. C. R. Acad. Sci. III 322: 633-650.

Ladefoged K., 1952. The periodicity of wood formation, Det Kongel Danske Vidensk Selsk Skrift Dan Biol 7: 1-98.

Larson P.R., 1964. Contribution of different-aged needles to growth and wood formation of young red pines. For. Sci. 10: 224-238.

Larson P.R., 1969. Wood formation and the concept of wood quality. Yale University, School of Forestry, $54 \mathrm{p}$.

Little C.H.A. and Wareing P.F., 1981. Control of cambial activity and dormancy in Picea sitchensis by indol-3-ylacetic and abscisic acid. Can. J. Bot. 59: 1480-1493.

Minchin P.E.H. and Lacointe A., 2005. New understanding on phloem physiology and possible consequences for modelling long-distance carbon transport. New Phytol. 166: 771-779.

O'Reilly C. and Owens J.N., 1989. Shoot, needle, and cambial growth phenology and branch tracheid dimensions in provenances of lodgepole pine. Can. J. For. Res. 19: 599-605.

Oribe Y., Funada R., and Kubo T., 2003. Relationships between cambial activity, cell differentiation and the localisation of starch in storage tissues around the cambium in locally heated stems of Abies sachalinensis (Schmidt) Masters. Trees 17: 185-192.

Oribe Y., Funada R., Shibagaki M., and Kubo T., 2001. Cambial reactivation in locally heated stems of the evergreen conifer Abies sachalinensis (Schmidt) Masters. Planta 212: 684-691.

Renninger H.J., Gartner B.L., and Grotta A.T., 2006. No correlation between latewood formation and leader growth in Douglas-fir saplings. IAWA J. 27: 183-191.

Rensing K.H. and Owens J.N., 1994. Bud and cambial zone phenology of lateral branches from Douglas-fir (Pseudotsuga menziesii) seedlings. Can. J. For. Res. 24: 286-296.

Rossi S., Anfodillo T., and Menardi R., 2006a. Trephor: a new tool for sampling microcores from tree stems. IAWA J. 27: 89-97.

Rossi S., Deslauriers A., and Anfodillo T., 2006b. Assessment of cambial activity and xylogenesis by microsampling tree species: an example at the Alpine timberline. IAWA J. 27: 383-394.

Rossi S., Deslauriers A., Anfodillo T., and Carrer M., 2008. Agedependent xylogenesis in timberline conifers. New Phytol. 177: 199-208.

Rossi S., Deslauriers A., Anfodillo T., Morin H., Saracino A., Motta R., and Borghetti M., 2006c. Conifers in cold environments synchronize maximum growth rate of tree-ring formation with day length. New Phytol. 170: 301-310.

Rossi S., Simard S., Rathgeber C.B.K., Deslauriers A., and De Zan C., Effects of a 20-day-long dry period on cambial and apical meristem growth in Abies balsamea seedlings. Trees: 23: 85-93. 
Savidge R.A., 1988. Auxin and ethylene regulation of diameter growth in trees. Tree Physiol. 4: 401-414.

Savidge R.A. and Wareing P.F., 1982. Apparent auxin production and transport during winter in the nongrowing pine tree. Can. J. Bot. 60: 681-691.

Schmitt U., Möller R., and Eckstein D., 2000. Seasonal wood formation dynamics of beech (Fagus sylvatica L.) and blck locust (Robinia pseudoacacia L.) as determined by the "pinning" technique. J. Appl. Bot. 74: 10-16.

Schweingruber F.H., 1996. Tree rings and environment dendroecology. Swiss Federal Institute for Forest, Snow and Landscape Research, Berne, Stuttgart, Vienna, 609 p.

Seo J.-W., Eckstein D., Jalkanen R., Rickebusch S., and Schmitt U., 2008. Estimating the onset of cambial activity in Scots pine in northern Finland by means of the heat-sum approach. Tree Physiol. 28: $105-112$.

Sundberg B., Little C.H.A., Cui K., and Sandberg G., 1991. Level of endogenous indole-3-acetic acid in the stem of Pinus sylvestris in relation to the seasonal variation of cambial activity. Plant Cell Environ. 14: 241-246.
Sundberg B. and Uggla C., 1998. Origin and dynamics of indoleacetic acid under polar transport in Pinus sylvestris. Physiol. Plant. 104: 22-29.

Sundberg B., Uggla C., and Tuominen H., 2000. Cambial growth and auxin gradients. In: Savidge R., Barnett J., Napier R. (Eds.), Cell and molecular biology of wood formation, BIOS Scientific Publishers Ltd, Oxford, pp. 169-183.

Tang Z., Chambers J.L., Guddanti S., Yu S., and Barnett J.P., 1999. Seasonal shoot and needle growth of loblolly pine responds to thinning, fertilisation, and crown position. For. Ecol. Manage. 120: 117-130.

Tuominen H., Puech L., Fink S., and Sundberg B., 1997. A radial concentration gradient of indole-3-acetic acid is related to secondary xylem development in hybrid aspen. Plant Physiol. 115: 577-585.

Uggla C., Magel E., Moritz T., and Sundberg B., 2001. Function and dynamics of auxin and carbohydrates during earlywood/latewood transition in Scots pine. Plant Physiol. 125: 2029-2039.

Uggla C., Mellerowicz E.J., and Sundberg B., 1998. Indole-3-acetic acid controls cambial growth in Scots pine by positional signaling. Plant Physiol. 117: 113-121. 